\title{
Ytinlärning och djupinlärning - en kritisk reflektion kring normativa tolkningar av begrepp i den samtida högskolepedagogiska diskursen
}

\author{
Richard Pleijel \\ Uppsala universitet
}

\begin{abstract}
I denna artikel diskuteras begreppen ytinlärning och djupinlärning. Artikeln syftar till en kritisk granskning av hur dessa två begrepp präglar olika sätt att tala om lärande, främst i en samtida, praktiskt orienterad högskolepedagogisk kontext. I artikeln argumenterar jag för att begreppsparet genom att kontrastera yta mot djup har en inneboende normativ potential, varigenom vissa sätt att lära implicit värderas som bättre än andra. I takt med att begreppsanvändningen har avlägsnats alltmer från den ursprungliga forskningskontext där de myntades, har den normativa potentialen gradvis kommit att realiseras. Detta har skett inte minst genom att begreppen har förbundits med andra, tydligt värderande termer, vilket har tenderat att förstärka det normativa draget hos begreppen. Detta beläggs och diskuteras i artikeln utifrån ett antal exempel från en nutida svensk högskolepedagogisk diskurs. Artikelns bärande idé är att det är nödvändigt med en kritisk reflektion, inte bara kring vad vi säger om lärande, utan också kring hur vi säger det.
\end{abstract}

Nyckelord: Ytinlärning, djupinlärning, Göteborgsskolan, fenomenografi, metaforer

\section{INLEDNING, SYFTE OCH UPPLÄGG}

Begreppsparet ytinriktad-djupinriktad lärstrategi är "av fundamental betydelse för den universitetspedagogiska diskussionen" - det menar Maja Elmgren och Ann-Sofie Henriksson i läroboken Universitetspedagogik (20I6, s. 2O-2I). Syftet med föreliggande artikel är en kritisk reflektion kring vad detta begreppspar egentligen har för "fundamental betydelse" och hur det präglar vårt sätt att tala om lärande i en högskolepedagogisk kontext. I fokus står den nutida, praktiskt orienterade svenska högskolepedagogiska diskursen, där begreppen alltjämt har en stor och till synes självklar spridning och användning. Av betydelse är också bakgrunden för begreppsparet ytinlärning-djupinlärning, det vill säga de sammanhang som var aktuella när begreppen myntades och började användas. Som jag vill försöka visa är detta av betydelse för att förstå begreppens användning också i en samtida kontext. Inte minst är det viktigt för att förstå den normativa prägel som jag menar att begreppen har kommit att få över tid. Artikeln utgår från ett projektarbete jag som doktorand gjorde när jag gick den högskolepedagogiska grundkursen vid Uppsala universitet HT20I4. I samband med kursen hade jag anledning att på olika sätt reflektera över den kurslitteratur som användes och framför allt över vad som där framställdes kring olika typer av lärande. Reflektionerna jag gjorde i samband med kursen och projektarbetet har på olika sätt fortsatt att vara aktuella för mig, varför jag har velat utveckla dem i denna form.

*Författarkontakt: richard.pleijel@yahoo.com 
Upplägget för artikeln är följande. I det inledande avsnittet undersöker jag användningen av begreppsparet ytinlärning-djupinlärning i en samtida svensk högskolepedagogisk diskurs. Genom ett antal exempel från olika typer av litteratur visar jag hur begreppen används till synes okritiskt och på ett sätt som tydligt värderar djupinlärning som något "bättre" jämfört med ytinlärning, som framställs som något "sämre". Därefter spårar jag begreppen tillbaka till den så kallade Göteborgsskolans forskning från andra halvan av 1970-talet. Särskild vikt läggs vid den begreppsapparat som Göteborgsskolans forskare använde för att tolka sina forskningsresultat. I nästa stycke fördjupar jag den kritiska diskussionen kring begreppen och framhåller den normativa, värderande karaktär som de har haft och alltmer kommit att få. Med hülp av George Lakoffs och Mark Johnsons (1980) metaforteori föreslår jag att begreppsparet ytinlärning-djupinlärning kan förstås som ett utflöde av de spatiala metaforerna Lära på ytan respektive Lära på djupet, där "ytligt" värderas som sämre genom att kontrasteras mot "djupt". Denna värdering är implicit genom de mer allmänna associationer som metaforerna eller begreppen för med sig, vilket jag benämner en normativ potential. Genom att metaforerna fram till idag har avlägsnats från sin ursprungliga kontext framstår de sannolikt som mer förgivettagna än vad de ursprungligen gjorde. Detta, tillsammans med att de har kommit att förbindas med andra tydligt värderande termer, menar jag kan förstås som att begreppens normativa potential gradvis har realiserats. Därmed förs diskussionen tillbaka till de inledande exemplen från den samtida mer praktiskt orienterade högskolepedagogiska diskursen. Artikeln avslutas med några sammanfattande tankar och en förhoppning om en i positiv bemärkelse kritisk reflektion kring hur vi talar om lärande.

Artikeln är i huvudsak baserad på ett litteraturstudium, där jag via olika sökverktyg (framför allt Libris och Google scholar) har identifierat och därefter närläst verk (avhandlingar, rapporter, uppsatser) på svenska som diskuterar begreppen ytinlärning-djupinlärning. Eftersom det är den samtida högskolepedagogiska diskursen som är det huvudsakliga intresset har jag begränsat mig till litteratur från de senaste 20 åren (förutom när jag tecknar bakgrunden för begreppen samt adresserar en del av den kritik som internationell forskning riktat mot begreppen). Artikeln avser inte att vara heltäckande; däremot har jag strävat efter att ha med så många olika exempel att diskussionen kan anses som representativ för en samtida, praktiskt orienterad svensk högskolepedagogisk diskurs.

\section{BEGREPPSPARET YTINLÄRNING OCH DJUPINLÄRNING I DEN SAMTIDA HÖGSKOLEPEDAGOGISKA DISKURSEN}

Elmgren och Henriksson menar alltså i sin bok Universitetspedagogik (2016) att begreppsparet ytinriktad-djupinriktad lärstrategi är "av fundamental betydelse för den universitetspedagogiska diskussionen" (s. 20-2I). Det är inte ointressant att detta hävdas i just denna bok: genom sin utformning och spridning - tre upplagor på bara sex år (2010/2013/20I6), dessutom översatt till engelska och utgiven i två upplagor (2014/2018) - framstår den redan som något av ett standardverk. Det kan därför vara lämpligt att börja framställningen i detta stycke, som avser att undersöka användningen av begreppsparet ytinlärning-djupinlärning i en samtida högskolepedagogisk diskurs, genom att titta närmare på just denna bok.

Elmgren och Henriksson (2016) inleder sin framställning av de två olika lärstrategierna med att diskutera begreppen "atomistisk kunskapssyn" respektive "holistisk kunskapssyn" (s. I8-19). De skildrar hur det pedagogiska idealet har utvecklats från den atomistiska till den holistiska kunskapssynen. Den senare innebär "att helheten ses som något mer än summan av de enskilda delarna, kunskapen kontextualiseras och sätts i ett sammanhang. Delarna är snarare aspekter 


\section{Richard Pleijel}

av helheten än delar som bygger upp den” (s. 19). Atomistisk respektive holistisk kunskapssyn kopplas därefter till begreppen ytinriktad respektive djupinriktad lärstrategi, där det första anses motsvara en atomistisk kunskapssyn och det andra en holistisk. Jag citerar ett längre stycke:

Man kan närma sig det som ska läras på olika sätt. Någon som enbart försöker memorera så mycket som möjligt sägs använda en ytinriktad lärstrategi, medan en som försöker förstå meningen och det huvudsakliga budskapet använder en djupinriktad lärstrategi. [...]

Begreppen holism-atomism och djupinriktat-ytinriktat relaterar till varandra. Ett djupinriktat lärande är svårt att åstadkomma om inte de olika delarna integreras till en större helhet. Redan de som myntade begreppen kopplade samman dem (Marton, 1977). Ibland ser man det hopskrivet, atomistiskt ytinriktat och holistiskt djupinriktat. [...]

Begreppen har en fundamental betydelse för den universitetspedagogiska diskussionen. En djupinriktad strategi är en förutsättning för ett gott lärande. Studenter med en djupinriktad lärstrategi söker efter mening och centrala budskap, efter sammanhang och principer. [...] Med en ytinriktad lärstrategi försöker personen att minnas så många detaljer som möjligt, utan att ta ställning till vilka som är mest väsentliga och utan att sammanfoga dem till en helhet. Långa passager kan läras in men kanske utan att förstås. (Elmgren \& Henriksson, 20I6, s. 20-2I)

Som framgår av citatet ovan konstaterar Elmgren och Henriksson att redan "de som myntade begreppen" - det vill säga atomism-holism och djupinriktat-ytinriktat - "kopplade samman dem (Marton, 1977)." Referensen är till boken Inlärning och omvärldsuppfattning (1977, senaste upplaga 20I4), författad av fyra företrädare för den så kallade Göteborgsskolan (Ference Marton, Lars Owe Dahlgren, Lennart Svensson och Roger Säljö), också förknippad med den fenomenografiska forskningstraditionen. Elmgrens och Henrikssons bok är ett av många exempel på verk som för vidare den begreppsapparat som kan spåras tillbaka till Göteborgsskolans forskare. Några andra, nutida exempel som kan nämnas är den av Thomas Hansson redigerade Pedagogik för högskolelärare (2016) samt den av Martin Stigmar redigerade volymen Högskolepedagogik. Att vara professionell som lärare i högskolan (2009). Särskilt Stigmars bok är mycket spridd. Dessutom kan olika pedagogiska specialarbeten, forskningsrapporter och akademiska avhandlingar nämnas i sammanhanget (t.ex. Rosén et al., 1998; Hedin, 2006; Olsson, 2007; Forslund Frykedal, 2008; Sjöblom, 20IO; Lundberg, 20I3; Karlsson, 20I5; Öhrstedt, 20I7). Jag ska ge ett antal specifika exempel ur denna litteratur på hur den använder och reproducerar begreppen ytinlärning (ytinriktat lärande) respektive djupinlärning (djupinriktat lärande). Genomgången avser att illustrera det normativa draget i användningen och framställningen av begreppen.

Det ytinriktade lärandet anses till exempel handla om att "besvara frågor mer än att förstå innehållet" (Fransson, 20I6, s. 48). Djupinriktat lärande, å andra sidan, kopplas till en högre ambitionsnivå hos studenten (Zambrell, 2013, s. 139). Stigmar (2009) menar att lärandets önskvärda utveckling går från "överföring" till "aktivt lärande" (s. 38); det förra innebär alltså ett passivt lärande eller, med andra ord, ett ytinriktat lärande. Ingen kan tveka om vad som är önskvärt. Schyberg (2009) säger därför helt frankt att ytinriktat lärande är "icke önskvärt" (s. 5I). Det som konceptualiseras som ytinriktat lärande förbinds vidare med "meningslöshet" samt med studentens "rädsla att misslyckas" (Öhrstedt, 20I7, s. 43). Hos Maltén (2002) länkas ytinlärning till "kvasikunskap". I en antologi från Högskolan i Gävle antyds det till och med att ytinriktat lärande, som premierar "snabba fakta", riskerar att leda till att studenter fuskar eller plagierar (Fransson, 20I2, s. 54). I vissa fall kan det normativa vara mer subtilt. En titel som "Djupinlärning trots dålig pedagogik eller ytinlärning trots god pedagogik?" (Alveteg \& Wingren, 2006) 
innebär till exempel en implicit men ändå tydlig värdering av djupinlärning respektive ytinlärning genom att associera dessa begrepp med orden "bra" respektive "dålig". Många flera exempel skulle kunna lämnas. Det som exemplen har gemensamt är att de ursprungliga begreppen ytinlärning-djupinlärning förbinds med andra termer och begrepp som tenderar att vara än mer värderande. Därmed förstärks den normativa karaktären hos de ursprungliga begreppen. Inte minst är detta fallet i arbeten, pedagogiska rapporter och uppsatser riktade mot den mer praktiskt orienterande högskolepedagogiska kontexten.

Det är naturligtvis inte ovanligt att forskare på olika sätt differentierar eller nyanserar begreppen ytinlärning-djupinlärning, kanske särskilt med avseende på den skarpa åtskillnaden mellan de två (t.ex. Hedin, 2006, s. 315-320). Detta förändrar dock inte i grunden associationerna som begreppen för med sig. Det gäller också om de två begreppen kompletteras med ytterligare ett (t.ex. Olsson, 2007, som arbetar med ytinriktade, djupinriktade och prestationsinriktade studiemönster). En särskilt typ av problematik uppstår enligt min mening när forskare eller studenter inte endast refererar de ursprungliga begreppen ytinlärning-djupinlärning, som bland andra Marton och Säljö ju använde för att tolka och beskriva egen empirisk forskning, utan använder deras begrepp för att tolka resultaten av egna undersökningar. Till exempel: "Sjöblom (2010, s. 4off) har genom att studera kursplaner vid Ekonomihögskolan vid Linnéuniversitetet, konstaterat att det mest frekventa verbet vid formulering av förväntade studieresultat är 'förstå', vilket indikerar att djupinlärning avses" (Zambrell, 20I3, s. I50, min kurs.). I ett praktiskt arbete kring lärstilar där elever intervjuades om sina upplevelser av det egna lärandet uppfattades intervjusvaren antyda att "de [eleverna] lärt på djupet istället för bara ytligt" (Lennholm, 2005, s. 27). I ett arbete kring pedagogiska grundkurser vid Lunds Tekniska Högskola (Börjesson et al., 2013) frågade sig författarna "ifall det finns ett ytinriktat lärande" hos studenterna vid dessa kurser. Denna senare typ av exempel, från akademiska uppsatser och examensarbeten, visar enligt min mening på en dubbel problematik: dels har studenter själva tillgodogjort sig en viss begreppsapparat som de sedan använder för att tolka resultaten av sina egna undersökningar; dels för de därigenom vidare en specifik förståelse av begreppen som på så sätt ytterligare sprids i den mer praktiskt orienterade högskolepedagogiska diskursen.

Det finns också gott om exempel på hur olika typer av akademiska uppsatser, som de ovan refererade, använder begreppen ytinlärning och djupinlärning på ett tydligt värderande sätt. I en examensuppsats från Linköpings universitet förknippar författarna till exempel djupinlärning med ett "genuint intresse för ämnet", medan däremot ytinlärning förbinds med "yttre hot" och "ängslan" (Bylund \& Jacobsson, 1999, s. I2, med referens till Marton, Hounsell \& Entwistle, 2000 [1986]). Fler exempel skulle kunna lämnas. Kanske är inte det primära problemet att ett förutbestämt analysspråk används, vilket riskerar att endast bekräfta de slutsatser som redan är underförstådda genom själva begreppen. Ett större problem är den tydliga värdering av "djupt" lärande på bekostnad av "ytligt" lärande som kommer till uttryck i många av exemplen. Som jag ska försöka visa i det följande avsnittet kan denna problematik spåras tillbaka till det sammanhang där begreppen myntades för snart 50 år sedan.

\section{URSPRUNGET FÖR BEGREPPEN YTINLÄRNING OCH DJUPINLÄRNING: GÖTEBORGSSKOLAN OCH FENOMENOGRAFIN}

Som redan nämnts kan begreppen ytinlärning och djupinlärning spåras tillbaka till den så kallade Göteborgsskolan eller INOM-gruppen, som genomförde sin forskning vid Göteborgs universitet från andra halvan av 1970-talet (för en bakgrund, se Richardson, 2015). Dess forskningsresultat vann snabbt stor spridning, med ytinlärning (ytinriktat lärande) och djupinlärning 
(djupinriktat lärande) som centrala begrepp (se Marton, Dahlgren, Svensson \& Säljö, 1977). Webb (1997) framhåller att detta sammanföll med framväxten av högskolepedagogisk forskning under 1970- och 80-talen, vilket kan vara en förklaring till Göteborgsskolans genomslagskraft. En annan förklaring är att just begreppen ytinlärning-djupinlärning och den metafor de bygger på är enkel och tydlig, och att det var därför begreppen gjorde sådan succé (Howie \& Bagnall, 20I3). Begreppen ytinlärning-djupinlärning kom att bli så pass spridda att de numera betraktas som en "hörnsten" (foundation stone) inom högskolepedagogisk forskning och reflektion (Webb, 1997, s. 195), vilket ju också Elmgren och Henriksson (2016) ger uttryck för genom att tala om deras "fundamentala betydelse" (se ovan). Idén bakom begreppen beskrivs av Howie och Bagnall (2013, s. 392) till och med som ett paradigm i Kuhns (1962) bemärkelse.

Göteborgsskolans övergripande forskningsmetodik har ofta kommit att associeras med begreppet fenomenografi (Marton, 198I), vilket i sin tur gör att fenomenografin och begreppen ytinlärning-djupinlärning ofta kopplas samman (t.ex. Kroksmark, 2007). Bland de första av Göteborgsskolans studier var Marton och Säljö (1976) som utforskade hur studenter läste akademisk text i en artificiell experimentmiljö. Studenterna fick sedan besvara frågor kring sin läsupplevelse och hur de därigenom lärde sig. Att Marton och Säljö använde sig av intervjuer är centralt för vad som sedan kom att benämnas som den fenomenografiska metoden; den intresserar sig inte i första hand för fenomen i sig själva utan för människors upplevelser och beskrivningar av dessa fenomen (den andra ordningens perspektiv). Utifrån studenternas svar kunde Marton och Säljö dra vissa slutsatser. "Level of processing", det vill säga hur studenterna lärde sig, kopplades till "level of outcome", det vill säga vad studenterna lärde sig (Marton, 1976). Marton och Säljö fann att antingen fokuserade studenterna på att försöka förstå vad texten eller berättelsen ("the discourse") handlade om, eller så försökte de memorera själva texten eller berättelsen. Den första lärstrategin benämndes "deep level approach", det vill säga djupinriktning eller djupinriktat lärande, den senare "surface level approach", det vill säga ytinriktning eller ytinriktat lärande (för de svenska begreppen, se t.ex. Marton et al., 1977, s. 48-50). Det förra tolkades som ett aktivt lärande, det senare som ett passivt lärande.

Det passiva lärandet kan inte leda till att studenten lär på ett djupare, holistiskt plan. Därmed kan han eller hon inte heller utvecklas som människa och individ, vilket är lärandets djupare syfte (Marton et al., 1977). För att studenten ska kunna lära på ett mer kvalitativt sätt är det alltså nödvändigt att gå från ett ytinriktat lärande till ett djupinriktat lärande. I regel använder en student sig av båda lärstrategierna, men det är alltså önskvärt att studenten rör sig mot en högre grad av djupinriktat lärande (Marton \& Säljö, 2000). Hos Marton, Dall'Alba och Beaty (1993) finns en uppdelning i sex olika lärstrategier, vilket antyder en differentiering av den skarpa tudelningen i yt- respektive djupinlärning; de sex olika strategierna refereras dock tydligt till den ursprungliga dikotomin i bemärkelsen att tre av lärstrategierna kopplas till ett kvantitativt sätt att lära sig på, medan de tre andra lärstrategierna kopplas till ett kvalitativt sätt att lära sig på (Marshall, Summers \& Woolnough, 1999, s. 292). Därför menar t.ex. Purdie och Hattie (2002, s. I7) att det finns en hierarki mellan de olika lärstrategierna, en hierarki som skulle kunna ses som en implicit värdering av några av lärstrategierna på bekostnad av de andra.

Som redan nämnts spreds Göteborgsskolans forskningsresultat på bred front i samband med att högskolepedagogisk forskning växte fram under 1970- och 80-talen (Webb, 1997). Att denna utveckling skedde under just denna period tycks alltså ha haft betydelse för att Göteborgsskolans forskning blev så pass spridd som den blev. Denna forskningstradition är väl representerad i en stor mängd litteratur på svenska (t.ex. Rosén et al., 1998; Hedin, 2006; Olsson, 2007; 
Forslund Frykedal, 2008; Stigmar, 2009; Schyberg, 2009; Hegender \& Stigmar, 2013; Elmgren \& Henriksson, 20I6; Fransson, 20I6; Öhrstedt, 20I7). Den har även präglat en mängd internationella arbeten (t.ex. Entwistle, I988; Pask, 1988; Schmeck, 1988; Prosser \& Trigwell, 1999; Laevers, 2000; Biggs, 2003; Ramsden, 2003; Houghton, 2004).

\section{DEN NORMATIVA POTENTIALEN HOS BEGREPPEN YTINLÄRNING OCH DJUPINLÄRNING}

Det är alltså lätt att konstatera att Göteborgsskolans forskning fick snabb och stor spridning. Som bland andra Elmgren och Henriksson (2016) framhåller (se ovan avsnitt 2) var det Göteborgsskolans forskare som myntade begreppen ytinlärning respektive djupinlärning. Med andra ord var det ett sätt för dem att tolka, konceptualisera och strukturera sina forskningsresultat (empirin). Att vi har att göra med en konceptualisering och strukturering av forskningsresultat innebär att det inte finns något naturgivet eller självklart med de kategorier och begrepp som de använde för att tolka utfallet av sin forskning. Det är det första som kan konstateras. Det innebär att även om det inte skulle finnas någon anledning att ifrågasätta själva empirin, kan man fråga sig vad det innebär att Göteborgsskolan myntade och använde just begreppen ytinlärning (ytinriktat lärande) och djupinlärning (djupinriktat lärande).

En forskare som har gjort just detta är Graham Webb (1997). Webb menar att en problematik är att Göteborgsskolan eller fenomenografin är mer påverkad än den vill erkänna av Edmund Husserls fenomenologiska grundantagande: att människor har förmågan till direkt perception av olika fenomen opåverkat av historiska, sociala och intellektuella förutsättningar. Även fast den säger sig avvisa det husserlska antagandet, verkar Göteborgsskolan och den fenomenografiska forskningen hävda att struktureringen av forskningsresultaten härstammar direkt från rådata (Webb, 1997, s. 20I-202). Med andra ord tycks Webb antyda att den andra ordningens perspektiv enligt fenomenografin anses handla endast om de beforskade objekten - men inte om forskningssubjekten (det vill säga i det här fallet Göteborgsskolans forskare själva). Som Cou$\sin (2009)$ dock framhåller är fenomenografin "underpinned by the constructivist principle that we construct meanings of phenomena from an array of social and personal influences" (s. I84). Detta är alltså en princip, vilket borde innebära att den inte bara gäller forskningsobjekten utan också forskarna själva. "Vi” i Cousins formulering är ju alla människor, det vill säga såväl forskningsobjekt som -subjekt. Dessa senare konstruerar alltså mening utifrån de forskningsresultat de erhållit genom sina studier och experiment. Utifrån fenomenografins egen utgångspunkt kan begreppen ytinlärning och djupinlärning alltså betraktas som utfall av en meningskonstruktion.

Synpunkterna ovan tjänar som en introduktion till det följande, som avser att fördjupa diskussionen kring begreppen ytinlärning-djupinlärning utifrån vad som skulle kunna kallas för ett språkbruksperspektiv. För det första är det lätt att konstatera att begreppen över tid har kommit att på ett tydligt sätt värderas gentemot varandra, vilket borde ha framgått utifrån diskussionen av en rad exempel från nutida högskolepedagogisk diskurs (avsnitt 2 ovan). Detta fenomen är dock inte något som endast har uppstått över tid. Det är i själva verket en konsekvens av själva begreppen och då särskilt av begreppen såsom begreppspar, eftersom "yta" får mening och värde i relation till "djup" och vice versa. Detta har jag ovan (avsnitt I) uttryckt som att begreppsparet har en normativ potential. I anslutning till Howie och Bagnall (20I3, s. 394; jfr även Webb, 1997) menar jag att det är rimligt att argumentera för att de problem som kan kopplas till begreppen ytinlärning-djupinlärning i grund och botten är ett språkproblem. Med andra ord, och i mer allmän mening, är det alltså en fråga om vilka termer och begrepp vi använder för att benämna olika fenomen och koncept. 
För att fördjupa denna diskussion vill jag nu ta hjälp av den konceptuella metaforteori som George Lakoff och Mark Johnson (1980) har utvecklat. Deras utgångspunkt är att språkanvändning på ett grundläggande plan präglar vårt sätt att konceptualisera omvärlden. Lakoff och Johnson menar därför att metaforer inte endast är en typ av språklig utsmyckning, utan en integrerad del av vårt tänkande. Metaforerna strukturerar vårt sätt att uppfatta verkligheten, hur vi tänker och vad vi gör (Lakoff \& Johnson, I980, s. 4). Det finns därför en tydligt normativ aspekt av metaforer i mer generell bemärkelse. Många av de metaforer som Lakoff och Johnson undersöker, särskilt de konceptuella metaforerna, existerar i motsatspar vilket gör att den ena metaforen får mening först i relation till den andra och vice versa. Lakoff och Johnson tar bland annat som exempel de spatiala metaforerna Good is up ("bra är uppåt") respektive Bad is down ("dåligt är nedåt"). När det går bra för oss går det uppåt, när det går dåligt för oss går det nedåt. När det är högkunjunktur går börsen uppåt, när det är ekonomisk recession går den nedåt och så vidare. Den ena metaforen är meningslös utan den andra, eftersom de kontrasteras mot varandra: "uppåt" blir inte "bra" förrän det kontrasteras mot "nedåt" som "dåligt". Enligt Lakoff och Johnson (1999) är de spatiala koncept som denna typ av metaforer bygger på själva hjärtat i vårt "konceptuella system" (s. 30).

Detta sätt att resonera kring metaforer kan också, menar jag, användas för att diskutera begreppsparet ytinlärning-djupinlärning. Orden "yta" respektive "djup" fungerar nämligen här på ett sätt som motsvarar metaforerna Good is up respektive Bad is down, det vill säga att en rörelse i en viss riktning värderas som bättre än en rörelse i en annan riktning. Det är tydligt att detta fenomen präglar begreppsparet ytinlärning-djupinlärning i den bemärkelsen att det som är ytligt värderas som negativt, medan det som är djupt värderas som positivt. I allmän bemärkelse associerar vi det som ligger på ytan, det som är ytligt, med det som är simpelt, flackt och trivialt; det som går på djupet, det djupa, associerar vi däremot med det som är klartänkt, inträngande och kärnfullt. Associationerna är alltså enkelt uttryckt följande: djupt är positivt, ytligt är negativt. Överfört på begreppsparet ytinlärning-djupinlärning finner vi följande två spatiala metaforer: Lära på ytan och Lära på djupet. Den första metaforen för med sig negativa associationer, den andra positiva (se Howie \& Bagnall, 2013, s. 394, för en snarlik synpunkt). Det bör understrykas att detta fenomen aktualiseras just när de två begreppen speglas mot varandra, när de utgör ett begreppspar där begreppen står i ett hierarkiskt förhållande till varandra. Det bör också understrykas att den normativa potentialen uppstår just genom de mer allmänna associationer som "ytligt" respektive "djupt" för med sig.

I sin respons på Webbs (1997) kritik menar Entwistle (1997) att framgången för begreppsparet ytinlärning-djupinlärning inte bara beror på metaforens styrka, utan också på att den är baserad på solid empirisk forskning (s. 217). Detta har ifrågasatts (Richardson, 20I5; Howie \& Bagnall, 20I3). Oavsett vad tycks det i den mer praktiskt tillämpa(n)de diskussionen vara så att den empiriska basen för forskningen har hamnat i bakgrunden, vilket gör att tyngden läggs på metaforen - inte på den empiri som en gång har gett metaforen dess förklarande kraft. Detta kan ha flera orsaker. En, som jag ska återkomma till i det avslutande avsnittet, är att det har gått flera decennier sedan Göteborgsskolans ursprungliga forskning på 1970- och 80-talen. En annan är att mer praktiskt orienterade framställningar i flera fall kan vara summerande, i den bemärkelsen att de på ett effektivt och relativt kortfattat sätt vill kommunicera vissa grundläggande, generella idéer. Detta möjliggör inte fördjupande resonemang. Men resultatet - att metaforen okritiskt förs vidare - blir ändå detsamma. Den enligt min mening kanske viktigaste orsaken till att metaforens normativa drag förstärks över tid är att den förbinds med andra värderande eller normativa ord och termer. Detta var en grundläggande idé bakom diskussionen i avsnitt 2 
(ovan), där jag gick igenom ett antal exempel från en mer samtida högskolepedagogisk diskurs. När ytinlärning till exempel förbinds med det som är "icke önskvärt", med "kvasikunskap", "snabba fakta", "meningslöshet" och "ängslan", och djupinlärning på motsvarande sätt laddas med djupt positiva associationer, så gör detta att begreppen ytinlärning-djupinlärning framstår som än mer värderande. Detta är en direkt effekt av den normativa potential som ligger i begreppen såsom begreppspar och de allmänna associationer som "ytligt" respektive "djupt" för med sig. Att dessa associationer över tid kommer att förstärkas genom att förbindas med andra typer av värderande termer eller begrepp kan alltså uttryckas som att begreppens eller metaforens normativa potential realiseras.

Eftersom metaforer enligt Lakoff och Johnson strukturerar vårt sätt att uppfatta verkligheten, kan man dra slutsatsen att metaforerna Lära på djupet respektive Lära på ytan är tankemodeller som på liknande sätt strukturerar vårt sätt att tänka kring lärande, särskilt i en högskolepedagogisk kontext. Jag tror inte att detta är någon revolutionerande insikt i den bemärkelsen att jag är den första att reflektera kring denna problematik (jfr t.ex. Stålne, 20I4, s. I68). Däremot tror jag att vi alltför ofta så att säga befinner oss inne $\mathrm{i}$ vår språkanvändning och våra begreppssystem. Det är när vi tar ett steg utanför dem och ser på dem utifrån som vi kan upptäcka sådana här mönster.

\section{AVSLUTANDE REFLEKTIONER}

Som avslutning på denna artikel vill jag försöka att ytterligare tydliggöra den problematik som är förbunden med traderingen och användandet av begreppen ytinlärning-djupinlärning i en samtida högskolepedagogisk kontext. Det är den problematik som jag ovan har benämnt som realiseringen av begreppens normativa potential. Det handlar med andra ord om avståndet mellan myntandet av begreppen och begreppens fortsatta användning.

Ju större avståndet blir mellan Göteborgsskolans ursprungliga forskning under 1970- och 8o-talen, vilken ledde till att begreppen ytinlärning-djupinlärning myntades, desto större blir avståndet till det tolkande moment som ursprungligen ledde till att dessa begrepp myntades. Så här skulle man också kunna uttrycka det: när ett begrepp myntas faller bevisbördan på den som har myntat begreppet. Eftersom begreppet inte är allmänt accepterat ankommer det på forskaren att förklara och försvara begreppet så att det därefter kan tas upp av andra i forskarsamhället och så småningom etableras. När det däremot är allmänt vedertaget lever det vidare av egen kraft och kopplingen till den ursprungliga situationen där begreppet myntades hamnar i bakgrunden. När Göteborgsskolans horisont (för att använda Hans-Georg Gadamers metafor) hamnar längre och längre bort och avståndet ökar till den samtida högskolepedagogiska diskursens horisont, blir följden att resultatet av den ursprungliga tolkningen till sist framstår som en vedertagen sanning. Här skulle man kunna erinra om Friedrich Nietzsches ord om att det vi kallar "sanning" inte är annat än en "här av metaforer, metonymier, antropomorfismer, kort sagt en summa av mänskliga relationer som har stegrats poetiskt och retoriskt, tolkats, smyckats, och som efter långt bruk förefaller fasta, kanoniska och bindande för ett folk” (Nietzsche, 2005, s. 507).

Vad innebär då detta i en samtida högskolepedagogisk kontext? Jag menar att det inte är ointressant hur vi talar om studenters lärande och hur vi lär studenter att själva tala om lärande sitt eget såväl som andras. En bärande tanke i denna artikel har varit att det mänskliga språket har en inneboende potential till olika former av normativa eller värderande perspektiv. Desto viktigare är det att regelbundet försöka ta ett steg utanför vår egen, förgivettagna språk- och begreppsanvändning, och reflektera över varför vi talar om vissa saker på ett visst sätt samt vad det innebär och vilka konsekvenser det får. Begrepp som ytinlärning och djupinlärning, centrala i en samtida högskolepedagogisk diskurs, är inte endast beskrivande termer utan bär med sig 


\section{Richard Pleijel}

normativa associationer. I takt med att de framstår som en allt självklarare del av samma diskurs så ökar risken för att de framstår som en "sanning" i Nietzsches bemärkelse.

I artikeln har jag velat adressera denna problematik. Jag har haft för avsikt att kritiskt lyfta frågan om det normativa draget hos den begreppsanvändning som associerats med Göteborgsskolan och fenomenografin, och som därefter nästan har kommit att leva sitt eget liv. Denna begreppsanvändning har inneburit ett värderande sätt att tala om vissa typer av lärande som bättre på bekostnad av andra som sämre. Det har skett genom användandet av de spatiala metaforerna Lära på djupet respektive Lära på ytan, som har fătt sin normativa potential just såsom begreppspar där djup kontrasteras mot yta. Genom decennier av forskning och undervisning har dessa tankemodeller fortsatt att strukturera tänkandet kring lärande ända fram till en nutida svensk högskolepedagogisk diskurs. Begreppens normativa potential kan i allt högre grad sägas ha realiserats i takt med att de har blivit förbundna med ytterligare normativa termer. Att avståndet till den ursprungliga empirin ökat har dessutom inneburit att begreppen kommit att bli alltmer förgivettagna.

Jag vill understryka att denna artikel inte har haft för avsikt att utgöra en kritik av själva den forskning som Göteborgsskolan eller fenomenografin en gång utförde. Inte heller har min avsikt varit att kritisera mer samtida forskning i denna tradition. Jag har däremot haft för avsikt att kritiskt reflektera kring viss begreppsanvändning som går att spåra tillbaka till Göteborgsskolan och som - vilket egentligen är mer intressant - har levt vidare och därigenom tenderat att förstärka värderingen av vissa typer av lärande på bekostnad av andra. Med andra ord har jag velat rikta uppmärksamheten mot en form av språkproblematik i den samtida högskolepedagogiska diskursen. Därmed är det min förhoppning att de tankar jag har fört fram i denna artikel kan vara ett bidrag till en levande diskussion inte bara kring vad vi säger om lärande, utan också kring hur vi säger det.

\section{FÖRFATTARPRESENTATION}

Richard Pleijel (f. 1985) är teologie doktor i Gamla testamentets exegetik vid Uppsala universitet. Hans forskning rör sig i gränslandet mellan bibelvetenskap och översättningsvetenskap, med särskilt fokus på bibelöversättning. Han har undervisat vid Teologiska institutionen, Uppsala universitet och vid Tolk- och översättarinstitutet, Stockholms universitet.

\section{REFERENSER}

Alveteg, M. \& Wingren, C. (2006). Djupinlärning trots dålig pedagogik eller ytinlärning trots god pedagogik? I: LTH:s 4:e inspirationskonferens: Proceedings (opag.). Lund: Lunds tekniska högskola.

Biggs, J. (2003). Teaching for quality learning at university. Maidenhead: Open University Press.

Bylund, Y. \& Jacobsson, E. (1999). Yt- eller djupinlärning: förstår eleverna No-undervisningen? Examensarbete. Linköping: Institutionen för tillämpad lärarkunskap, Linköpings universitet.

Börjesson, E., Galbe, M., Johansson, E., Pauly, F. \& Petersson, L. (2013). Yt- och djupinriktat lärande på LTH:s grundläggande kurser - Matematik i fokus. Pedagogiskt arbete, Högskolepedagogisk introduktionskurs. Lund: Lunds tekniska högskola.

Cousin, G. (2009). Researching learning in higher education. An introduction to contemporary methods and approaches. London: Routledge.

Elmgren, M. \& Henriksson, A-S. (2016) [12010]. Universitetspedagogik. 3. uppl. Stockholm: Norstedts.

Entwistle, N. (1988). Styles of learning and teaching: an integrated outline of educational psychology for students, teachers and lecturers. London: Fulton.

Entwistle, N. (1997). Reconstituting approaches to learning: a response to Webb. Higher Education, 33, 213-218. 
Forslund Frykedal, K. (2008). Undervisning med grupparbete som arbetsform. Linköping: Institutionen för beteendevetenskap, Linköpings universitet.

Fransson, G. (2012). Fusk, lärande och kreativa genvägar - ett resonemang om hur lärare kan arbeta för att motverka studentfusk. I: G. Fransson \& H. Hammarström (Red.), I mötet mellan vetenskap och lärande - 13 högskolepedagogiska utmaningar (s. 45-66). Gävle: Högskolan i Gävle.

Fransson, G. (2016). Studieteknik och studiekompetens. I: T. Hansson (Red.), Pedagogik för högskolelärare (s. 42-69). Hedemora: Gidlunds.

Hansson, T. (Red.). (2016). Pedagogik för högskolelärare. Hedemora: Gidlunds.

Hedin, A. (2006). Lärande på hög nivå: idéer från studenter, lärare och pedagogisk forskning som stöd för utveckling av universitetsundervisning. Uppsala: Avdelningen för utveckling av pedagogik och interaktivt lärande, Uppsala universitet.

Hegender, H. \& Stigmar, M. (Red.). (2013). Universitetspedagogik i praktiken. Sexton lärartexter om pedagogisk utveckling. Kalmar: Linnéuniversitet.

Houghton, W. (2004). Engineering subject centre guide: learning and teaching theory for engineering academics. Loughborough: HEA Engineering Subject Centre.

Howie, P. \& Bagnall, R. (2013). A critique of the deep and surface approaches to learning model. Teaching in Higher Education, 18(4), 389-400.

Karlsson, N. (2015). Matematik i lärarutbildningen: Studenters kunskaper i och uppfattningar om matematik. Forskningsrapport från MIL- och SKUM-projekten. Huddinge: Södertörns högskola.

Kroksmark, T. (2007). Fenomenografisk didaktik - en didaktisk möjlighet. Didaktisk tidskrift, 17(2/3), 1-50.

Kuhn, T. S. (1962). The structure of scientific revolutions. Chicago: Chicago University Press.

Laevers, F. (2000). Forward to basics! Deep-level-learning and the experiential approach. Early Years, 20(2), $20-29$.

Lakoff, G. \& Johnson, M. (1980). Metaphors we live by. Chicago: Chicago University Press.

Lakoff, G. \& Johnson, M. (1999). Philosophy in the flesh. The embodied mind and its challenge to western thought. New York: Basic Books.

Lennholm, H. (2005). Att undervisa med olika lärstilar - en fallstudie frän den pedagogiska praktiken. Examensarbete. Växjö: Institutionen för pedagogik, Växjö universitet.

Lundberg, L. (2013). Studentens lärande i centrum. Sveriges forrenade studentkårer om pedagogik i högskolan. Stockholm: Sveriges förenade studentkårer.

Maltén, A. (2002). Hjärnan och pedagogiken - ett samspel. Lund: Studentlitteratur.

Marshall, D., Summers, M. \& Woolnough, B. (1999). Students' conceptions of learning in an engineering context. Higher Education, 38(3), 291-309.

Marton, F. (1976). What does it take to learn? Some implications of an alternative view of learning. I: N. Entwistle (Red.), Strategies for research and development in higher education (s. 32-42). Amsterdam: Swets \& Zeitlinger.

Marton, F. (1981). Phenomenography - describing concepts in the world around us. Instructional Science, 10, 177-200.

Marton, F., Dahlgren, L. O., Svensson, L. \& Säljö, R. (1977). Inlärning och omvärldsuppfattning. En bok om den studerande människan. Stockholm: Almqvist \& Wiksell.

Marton, F., Dall'Alba, G. \& Beaty, E. (1993). Conceptions of learning. International Journal of Educational Research, 19(3), 277-300.

Marton, F., Hounsell, D. \& Entwistle, N. (Red.). (2000 [1 1986]). Hur vi lär. 3. uppl. Övers. M. Asplund Carlsson. Stockholm: Rabén \& Sjögren.

Marton, F. \& Säljö, R. (1976). On qualitative differences in learning: 1. Outcome and process. British Journal of Educational Psychology, 46(1), 4-11.

Marton, F. \& Säljö, R. (2000 [1986]). Kognitiv inriktning vid inlärning. I: F. Marton, D. Hounsell \& N. Entwistle (red.), Hur vi lär (s. 56-80). Övers. M. Asplund Carlsson. 3. uppl. Stockholm: Rabén \& Sjögren.

Nietzsche, F. (2005). Samlade skrifter 2. Otidsenliga betraktelser I-IV. Efterlämnade skrifter 1872-1875. Övers. J. Asklund. Stockholm/Stehag: Symposion. 


\section{Richard Pleijel}

Olsson, U. (2007). Flexibel utbildning - för vem? Framgångsfaktorer i en universitetskurs. (Diss., Karlstad universitet.) Karlstad: Avdelningen för pedagogik, Karlstad universitet.

Pask, G. (1988). Learning strategies, teaching strategies, and conceptual or learning style. I: R. Schmeck (Red.), Learning strategies and learning styles (s. 83-99). New York: Springer.

Prosser, M. \& Trigwell, K. (1999). Understanding learning and teaching: the experience in higher education. Buckingham: Society for Research into Higher Education.

Purdie, N. \& Hattie, J. (2002). Assessing students' conceptions of learning. Australian Journal of Educational \& Developmental Psychology, 2, 17-32.

Ramsden, P. (2003). Learning to teach in higher education. 2. uppl. London: Routledge.

Richardson, J. (2015). Approaches to learning or levels of processing: what did Marton and Säljö (1976a) really say? The legacy of the work of the Göteborg group in the 1970s. Interchange, 46, 239-269.

Rosén, U., Horne, M., Ambjörn L., Bengtsson, R., Ristilammi, P-M. \& Holmqvist, K. (1998). Kursutveckling med sikte på djupinlärning. Lund: Universitetspedagogiskt centrum.

Schmeck, R. (Red.). (1988). Learning strategies and learning styles. New York: Springer.

Schyberg, S. (2009). Studentcentrering - förutsättning för studenters lärande? I: M. Stigmar (Red.), Högskolepedagogik. Att vara professionell som lärare i högskolan (s. 45-58). Stockholm: Liber.

Sjöblom, Å. (2010). Den goda examinationen - examinationsformers relation till förväntande studieresultat. Pedagogiskt arbete på grundnivå. Kalmar: Institutionen för pedagogik, psykologi och idrottsvetenskap, Linnéuniversitetet.

Stigmar, M. (2009). Att utvecklas som universitetslärarare. I: M. Stigmar (Red.), Högskolepedagogik. Att vara professionell som lärare $i$ högskolan (s. 32-44). Stockholm: Liber.

Stålne, K. (2014). Att bedöma komplexitet i läranderesultat: en jämförelse mellan SOLO-taxonomin och Model of Hierarchical Complexity. I: A. Persson \& R. Johansson (Red.), Vetenskapliga perspektiv på lärande, undervisning och utbildning $i$ olika institutionella sammanhang - utbildningsvetenskaplig forskning vid Lunds universitet (s. 159-174). Lund: Institutionen för utbildningsvetenskap, Lunds universitet.

Webb, G. (1997). Deconstructing deep and surface: towards a critique of phenomenography. Higher Education, 33(2), 195-212.

Zambrell, K. (2013). Resurser och examination. Utbildningsanslagens fördelning inom Linnéuniversitetet samt möjliga examinationsformer för resurssvaga ämnen. I: H. Hegender \& M. Stigmar (Red.), Universitetspedagogik i praktiken. Sexton lärartexter om pedagogisk utveckling (s. 139-160). Kalmar: Linnéuniversitet.

Öhrstedt, M. (2017). Högskolestudenters lärande. Ett lärstrategiskt perspektiv på studier i psykologi. (Diss., Stockholms universitet.) Stockholm: Psykologiska institutionen, Stockholms universitet. 